\title{
DEVELOPING A HEALTHY LIFESTYLE OF STUDENTS THROUGH THE PRACTICE OF SPORT ACTIVITIES
}

\author{
Ioan Sabin SOPA \\ "Lucian Blaga" University, Sibiu, Romania \\ sopa_sabin@yahoo.com \\ Marcel POMOHACI \\ "Lucian Blaga" University, Sibiu, Romania \\ marcelpomohaci@yahoo.com
}

\begin{abstract}
Sports activities and disseise prevention is a nowadays worldwide discussed problem, many specialists embraced the idea that physical activities can develop and maintain the health of human body. Our study was focused on finding the habits of a group of students from the University "Lucian Blaga" from Sibiu regarding physical activities, types of sports activities practiced in leisure time, student's concept about the values and importance of practicing sports activities and so on.

The main method of research was the lifestyle health questionnaire through which we investigated some aspects regarding sports activities influence on the level of health. We choose a sample of 300 students from all three years of study from different faculties from our university.

The results of our investigation showed that students are aware of the positive influence of sports activities on human body.
\end{abstract}

KEYWORDS: healthy lifestyle, sports activities, benefits of sport practice

\section{Introduction}

Health is a state of physical, mental and emotional well-being felt by persons of any age in their personal and social life. According to Neacşu, "the right to health, just as the right to good education, is one of the fundamental rights of any human being" (Neacşu, 2010).

Promotion of healthy lifestyles has been gaining popularity as a tool for developing public health. Studies indicated that healthy lifestyles enhance lifelong health, increase quality of life, and decrease morbidity and mortality (Ebem, 2007).

Lifestyle choices and individuals' behaviors have the potential to influence health and improve the quality of life (Lyons \& Langille, 2000). During the transition from childhood to adulthood, adolescents establish patterns of behavior and make lifestyle choices that affect both their current and future health (Nader et al., 2008; Telama, 2009).

Active and health-enhancing leisure time by outdoor physical activities can significantly increase the benefits of physical activities and facilitate adoption of a healthy lifestyle in children and adolescents, and can also be combined with the school environment (Fromel, 2017).

Specialists consider that health is not strictly a medical issue, but also a 
bio-psycho-social state. In brief, we can state that human health is a combination of several factors: biological, psychological and social (Zlate, 2010).

Sport and leisure roles contribute to health and to quality of life. Therefore, understanding the underlying experiences of the commitment to these roles continues to gain in importance (Shipway \& Holloway, 2010).

The development of contemporary society generates unprecedented quantitative and qualitative growth in all areas, including that of sports performance (Szabo, 2015).

The interest in preventing youth problems and promoting healthy youth development led to the implementation of strength-based approaches, which aimed to be empowering and effective in diverse contexts (Benson et al., 2006).

Lifestyle is an essential factor in a person's health status, obviously along with biological factors and the environment. The World Health Organization defines the concept of "health" as follows: health is "a state of complete physical, mental and social well-being and not merely the absence of disease or infirmity" (Rășcanu, 2010).

Lack of physical activities has led to the continuous increase of the percentage of the children who are overweighed (Canning et al., 2004; Elgar et al., 2005).

Health promoting lifestyles include activities that are focused on improving the level of well-being. The focus of these activities is on the development of positive potential for physical, social, mental, intellectual or spiritual health (Ebem, 2007). Specialists also found a growing interest of youth for sports activities, and also presented the consequences of lack of physical activity with negative effects on human life (obesity, excess in body mass index, deformation of the spine, heart problems etc.) also practicing sports activities can improve socialization, communication and friendships (Sopa et al., 2016).
From this perspective, physical activity is a component of an active life, an "important ingredient of lifestyle, which involves doing some sort of exercise according to one's own options, a few times a week; this exercise should be enjoyable, should consume energy and produce satisfaction" (Grigore, 2007).

Physical activity is a component of an active life, an "important ingredient of lifestyle, which involves doing some sort of exercise according to one's own options, a few times a week; this exercise should be enjoyable, should consume energy and produce satisfaction" (Grigore, 2007). In addition, sport practicing has a positive influence on the dexterity of the nondominant member, all the more so as the training is conducted in this respect and, on the other hand, whether the sport involves the use of both members equally (Baitel \& Pătru, 2018).

Unhealthy diets and physical inactivity are major contributors to overweight and obesity, which are among the leading risk factors for many non-communicable diseases (Kelishadi et al., 2008).

There is also evidence that regular physical education may reduce or prevent from mild or moderate depression (Yildirim, 2010).

A "healthy lifestyle" is an important component of the more general notion of "health" which includes several elements: avoiding any kind of abuse (alcohol, tobacco, unhealthy diets etc.), a systematic practice of physical activity either in an organized form or individually, as a leisure time activity with a recreational purpose, observing basic nutrition rules etc. A healthy lifestyle is always associated to good health, to an active life (Macovei, 2013).

\section{Aim of the Research}

The aim of our research was to identify the lifestyle habits of students from "Lucian Blaga" University Sibiu, and how sports activities influence their health and 
motor development. We also wanted to observe the concern with health improvement or maintenance, if students have a regular practice of physical exercises habit, if they are conscious of the long-term benefits that sports activities have on their health and body development, and also if they have a basic knowledge of hygiene rules, nutrition benefits and overcoming the obesity threats.

\section{Methods of the Research}

\subsection{The Place of the Research}

Our research took place in the university school year 2017-2018 at the "Lucian Blaga" University from Sibiu with students from four faculties: economy faculty, law faculty, engineering faculty and science faculty.

\subsection{Sample of the Research}

At the experiment attended 300 students from the four faculties mentioned above, and answered to the lifestyle habit questionnaire. Approximately 178 from the total number of those questioned, representing $59 \%$ from the total number of students, were female, and 122 students, representing $41 \%$ from the total, were male. Regarding faculty members that participated in our experiment the structure of the sample was: 75 students from the economy faculty represented $25 \%$ from the total number of subjects, 57 students from law faculty that represented $19 \%$, 69 students from the engineering faculty representing $23 \%$ from the total number of subjects, 99 students from the science faculty representing $33 \%$ from the total sample.

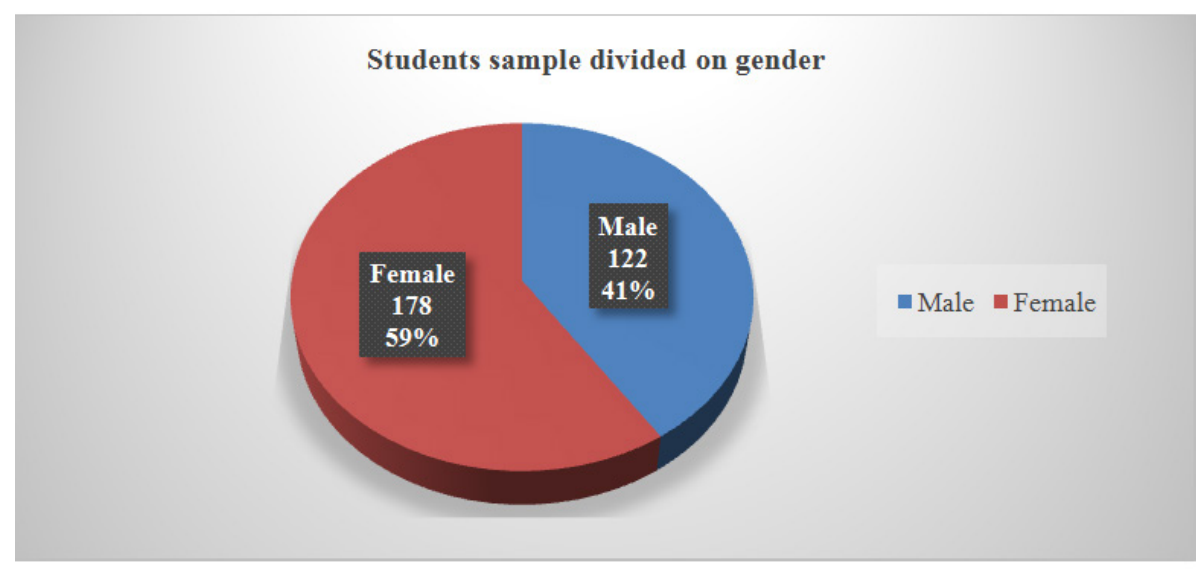

Figure no. 1: Students sample divided on gender

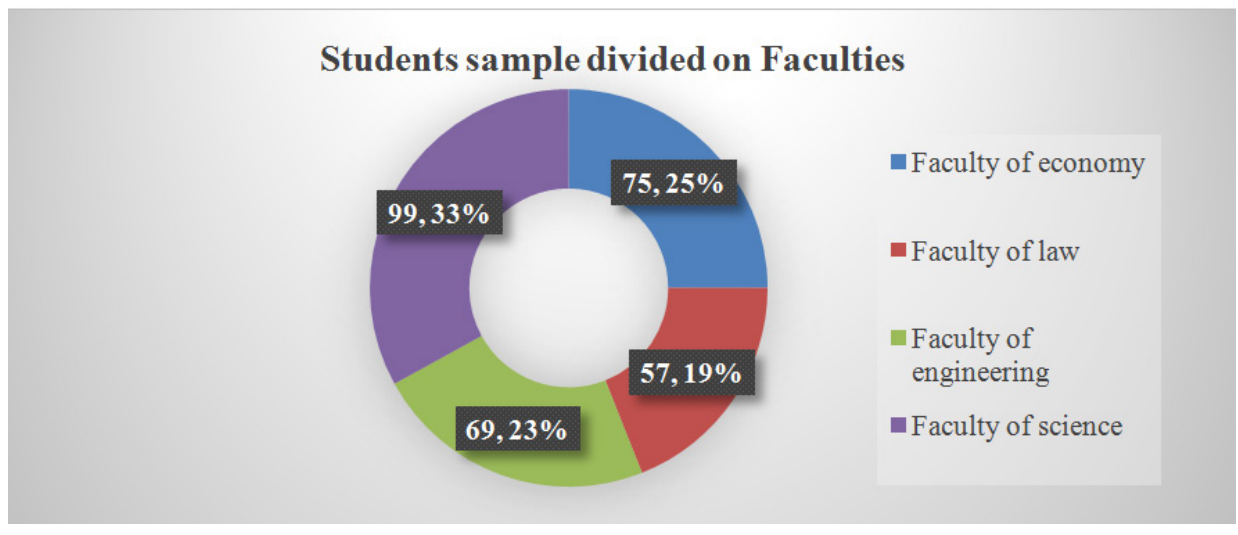

Figure no. 2: Students sample divided on Faculties 


\subsection{Methods of Research}

The method of the research used in our experiment was the questionnaire of lifestyle habits with five levels of answer on Likert scale. For the questionnaire of opinions we used the following references Dragnea, A. (2006), Cârstea, G. (2000) and Ionescu, C. (2012).

We used the following types of scales in building the questionnaire: nominal scale - used for the quantitative variables, interval scale - used for measuring the level of knowledge and attitudes regarding the items of the questionnaire, and Likert scale with five levels ( 5 - in very big accordance with the affirmation, 4 - in big accordance with the affirmation, 3 - in relative accordance or in equal measure with the affirmation, 2 - in little accordance with the affirmation, 1 - in very little accordance with the affirmation.

The questionnaire for students had 10 items that followed our research theme and had as aim to discover the lifestyle habits of students regarding sport practice.
Because the questionnaire wasn't a standard test we applied a pre-test on a 40 persons to determine the validity of our research method. After gathering the responses from our pre-test sample to see if the intern consistency of our questionnaire is valid we used the Alfa Cronbach coefficient with the help of the SPSS statistic program. The coefficient for a valid consistency questionnaire is between $0.70-1$ points, value that indicates the fidelity of the questionnaires.

The results of the questionnaire analyse and the value of Alfa Cronbach coefficient was 0.879 , so we can conclude that our questionnaire fidelity parameters are adequate.

\subsection{Results of the Research}

The first step in our investigation was to administrate a set of questions and to discover the opinions of students regarding the effects of sports activities on their body and mind.

Item 1. Does sports activities help in improving or maintaining health parameters?

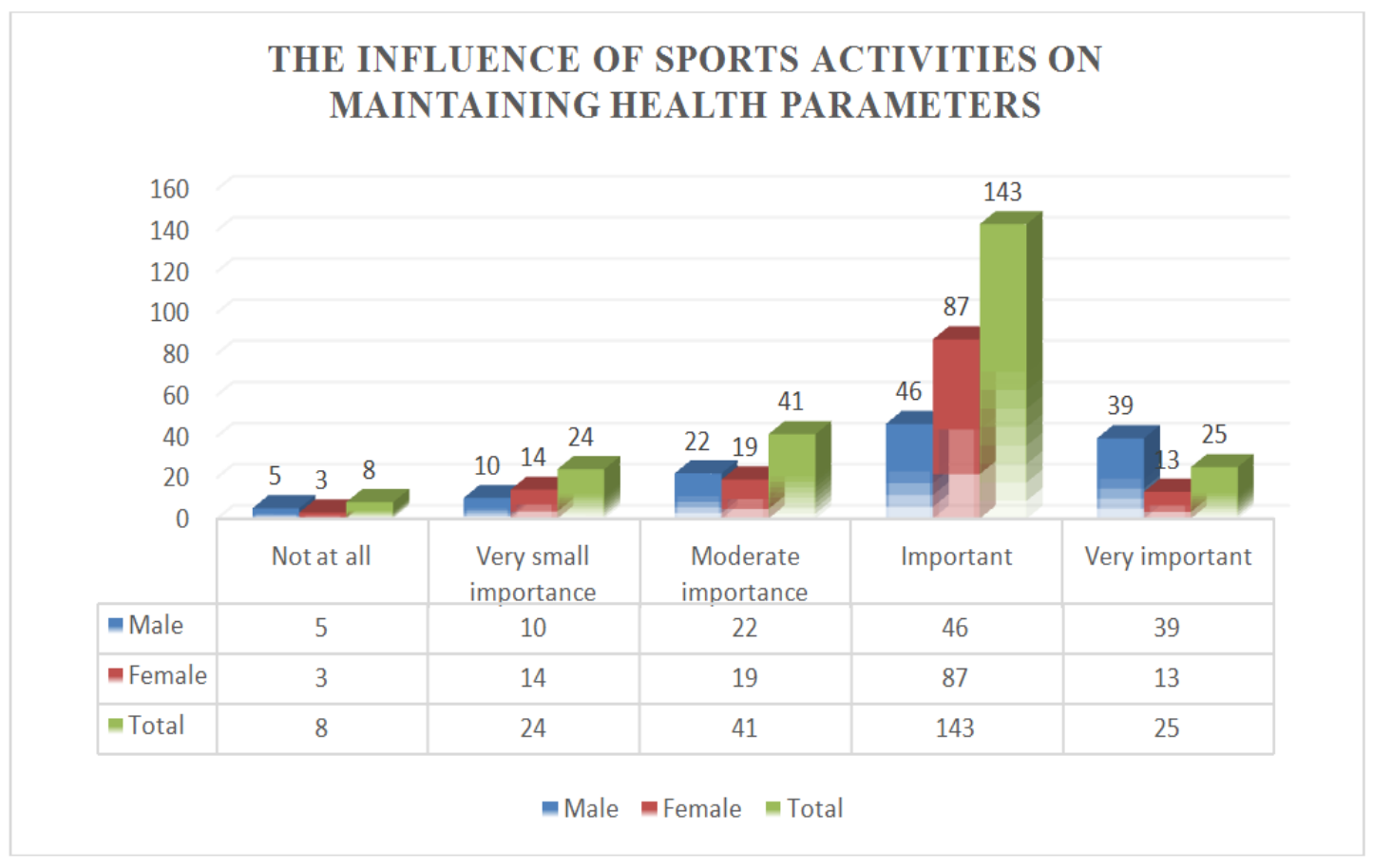

Figure no. 3: The influence of sports activities on maintaining health parameters 
Item 2. Are sports activities important in developing communication, socialization and making friendships?

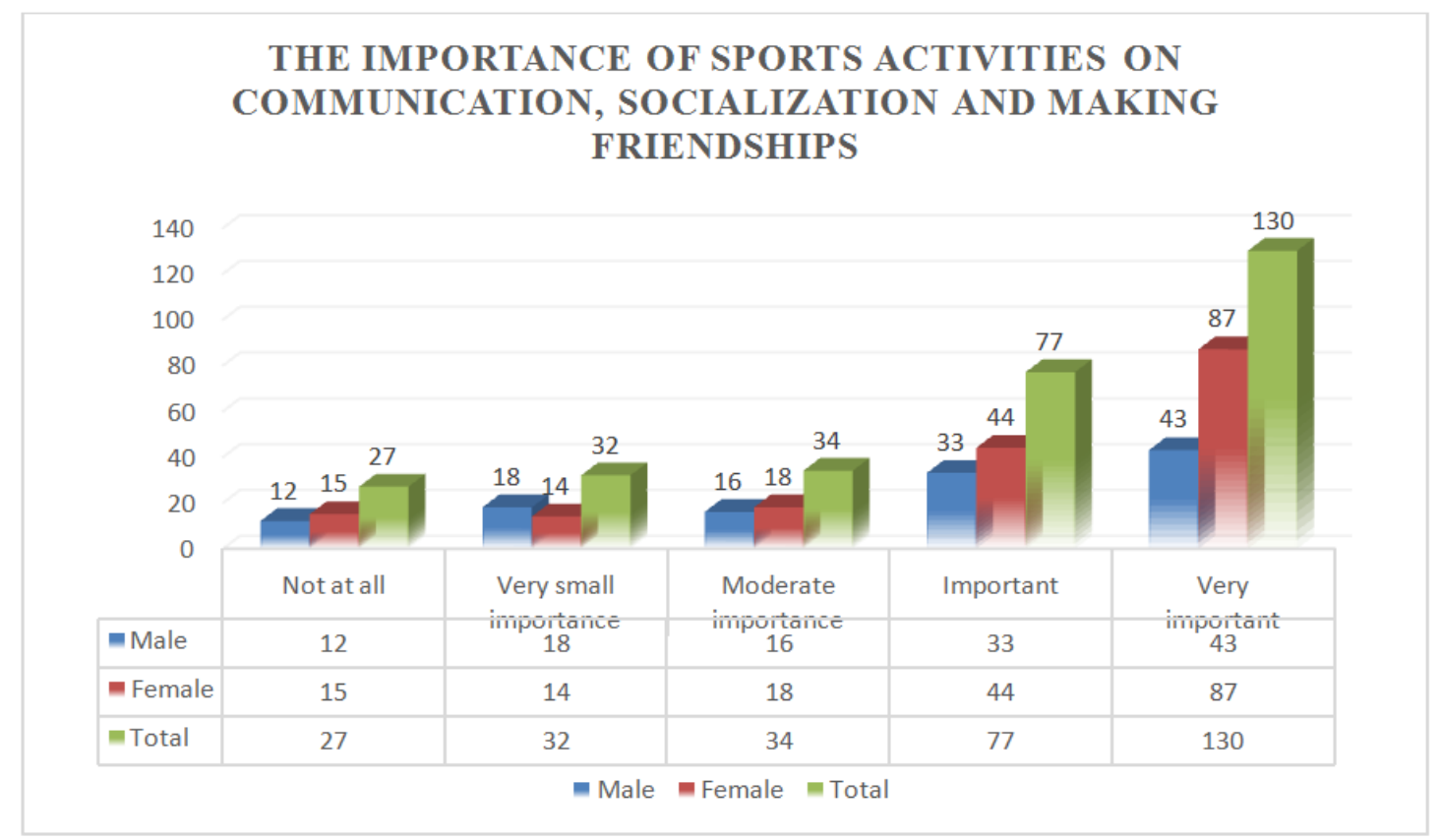

Figure no. 4: The importance of sports activities on communication, socialization and making friendships

Item 3. Does sports activities promote moral values such as self-respect, respect for the others, respect for laws and rules, loyalty, correctitude, dignity and discipline?

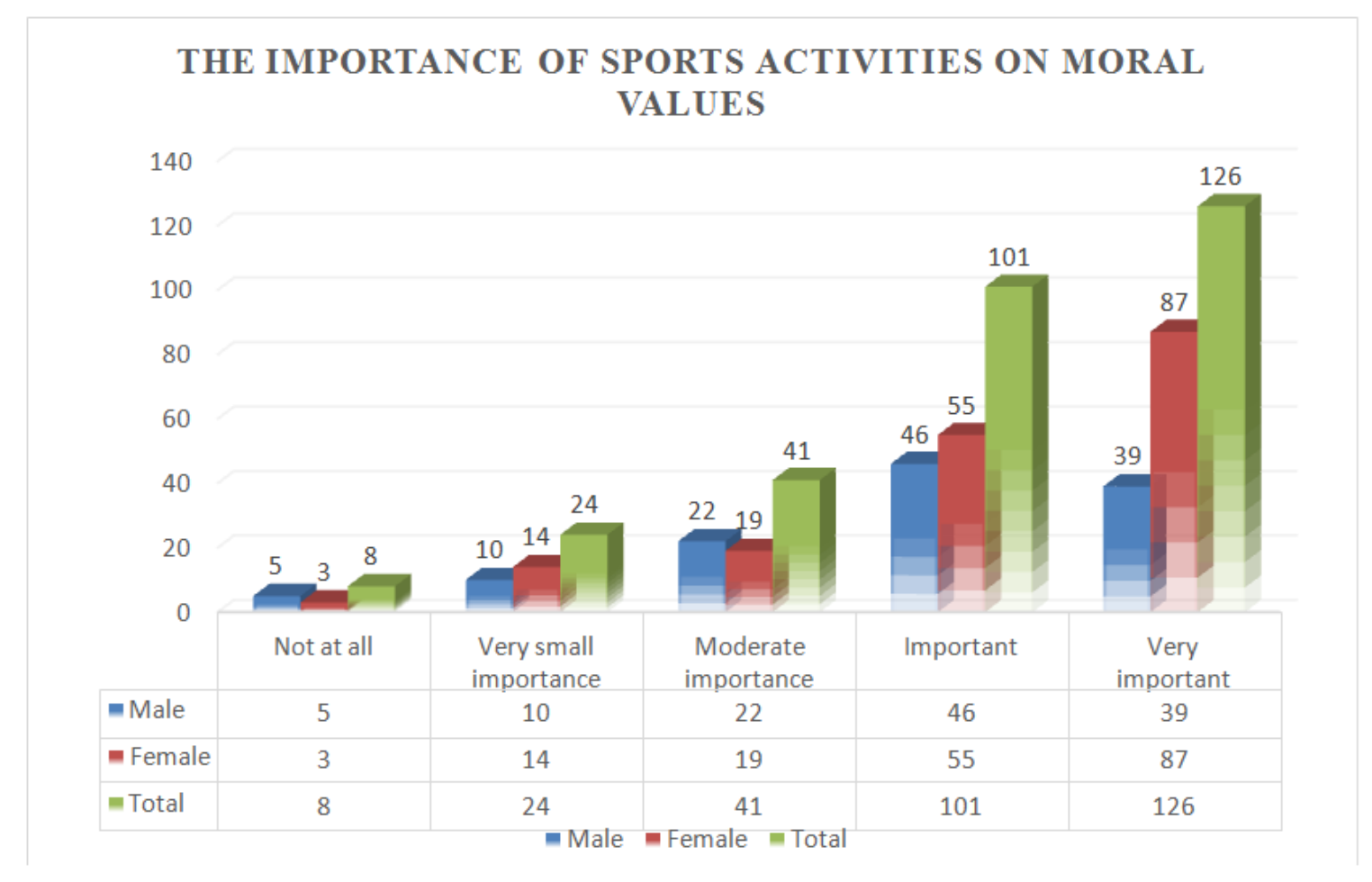

Figure no. 5: The importance of sports activities on moral values 
Item 4. Has sports activities real impact on social values as communication capacity, socialization, respect for the others, respect for the social rules, raised capacity for collaboration, respect for the colleagues activity?

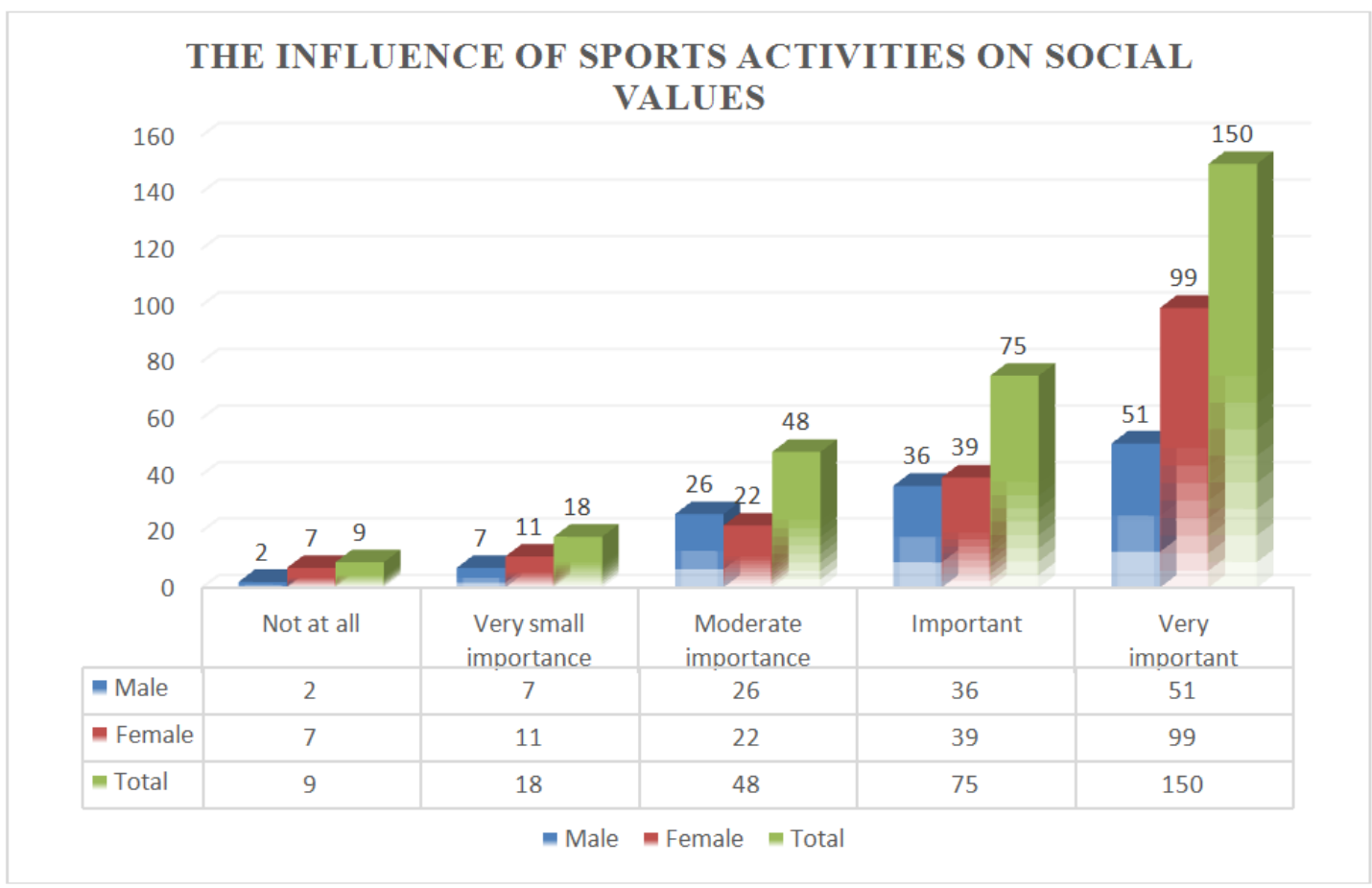

Figure no. 6: The influence of sports activities on social values

Item 5. Do sports activities improve motivation level?

\section{THE IMPACT OF SPORTS ACTIVITIES ON MOTIVATIONAL LEVEL}

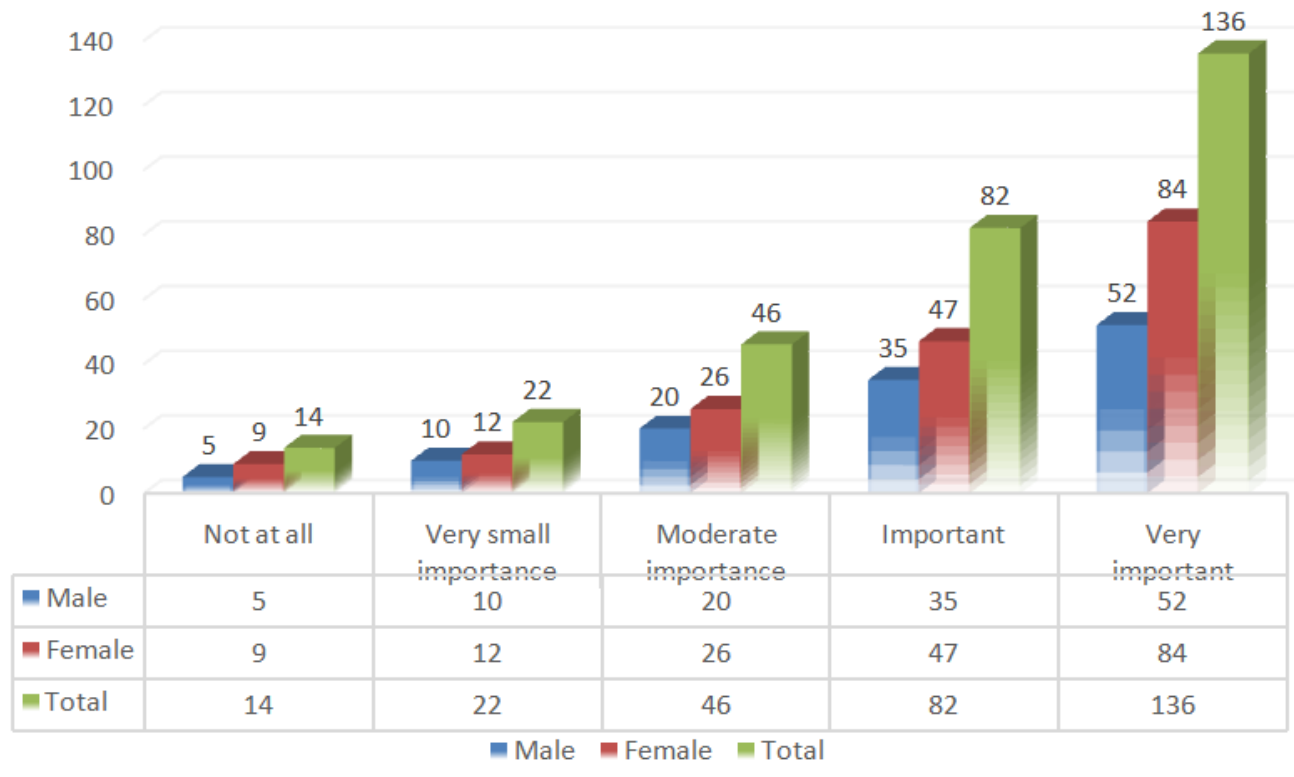

Figure no. 7: The impact of sports activities on motivational level 
Item 6. Sports activities improve the need for constant practice of sport, the desire for self-improvement and the need for knowing your physical limits.

\section{THE IMPACT OF SPORTS ACTIVITIES ON THE LEVEL OF SELF-IMPROVEMENT}

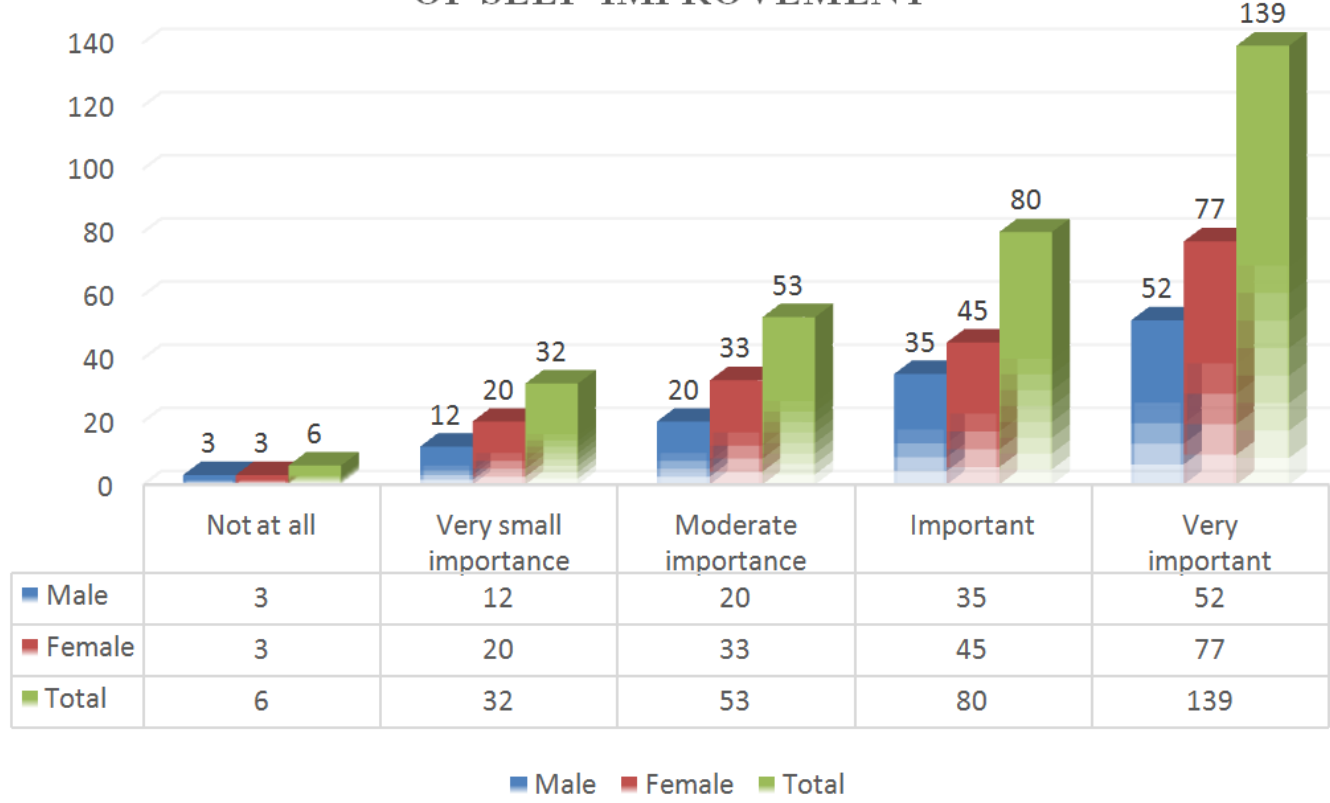

Figure no. 8: The impact of sports activities on the level of self-improvement

\section{THE INFLUENCE OF SPORTS ACTIVITIES ON MENTAL AND PHYSICAL RELAXATION}

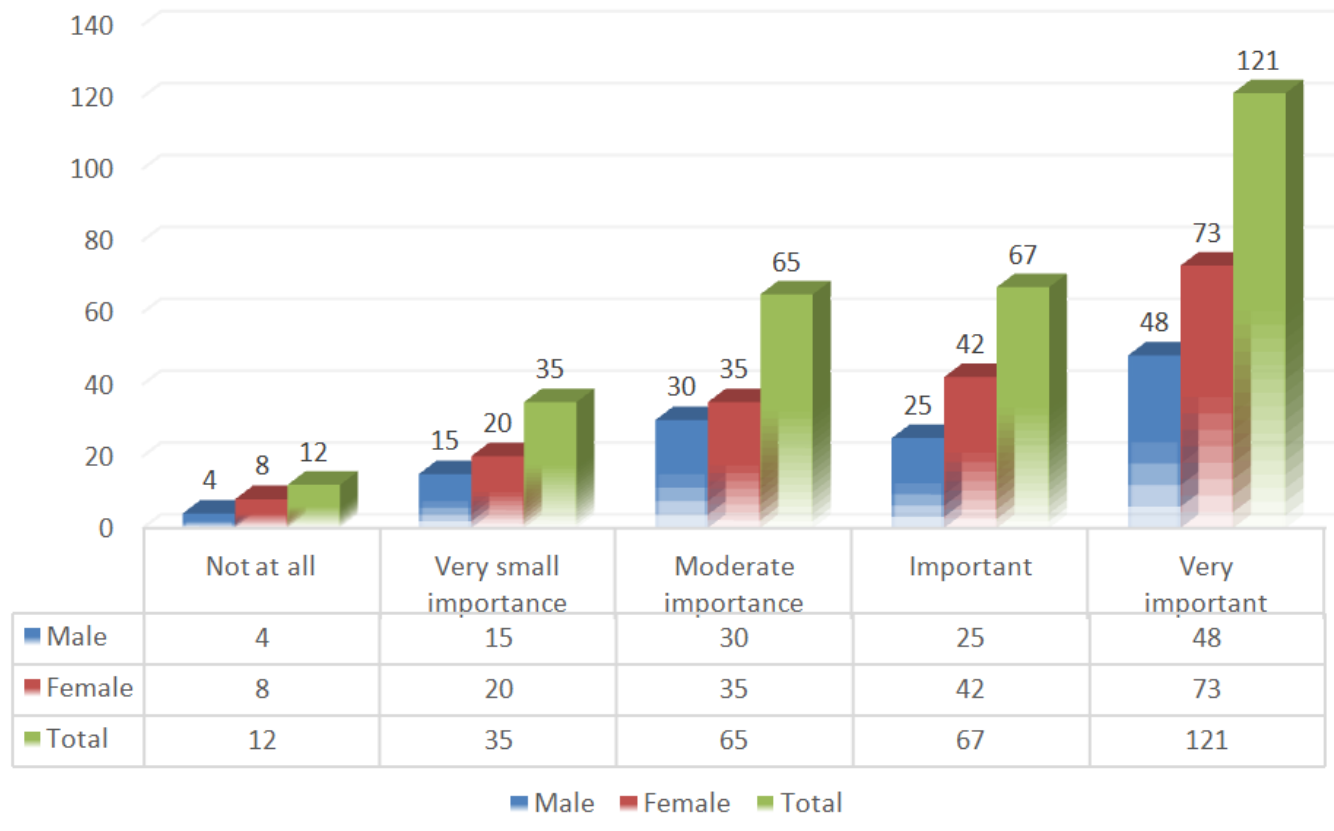

Figure no. 9: The influence of sports activities on mental and physical relaxation 


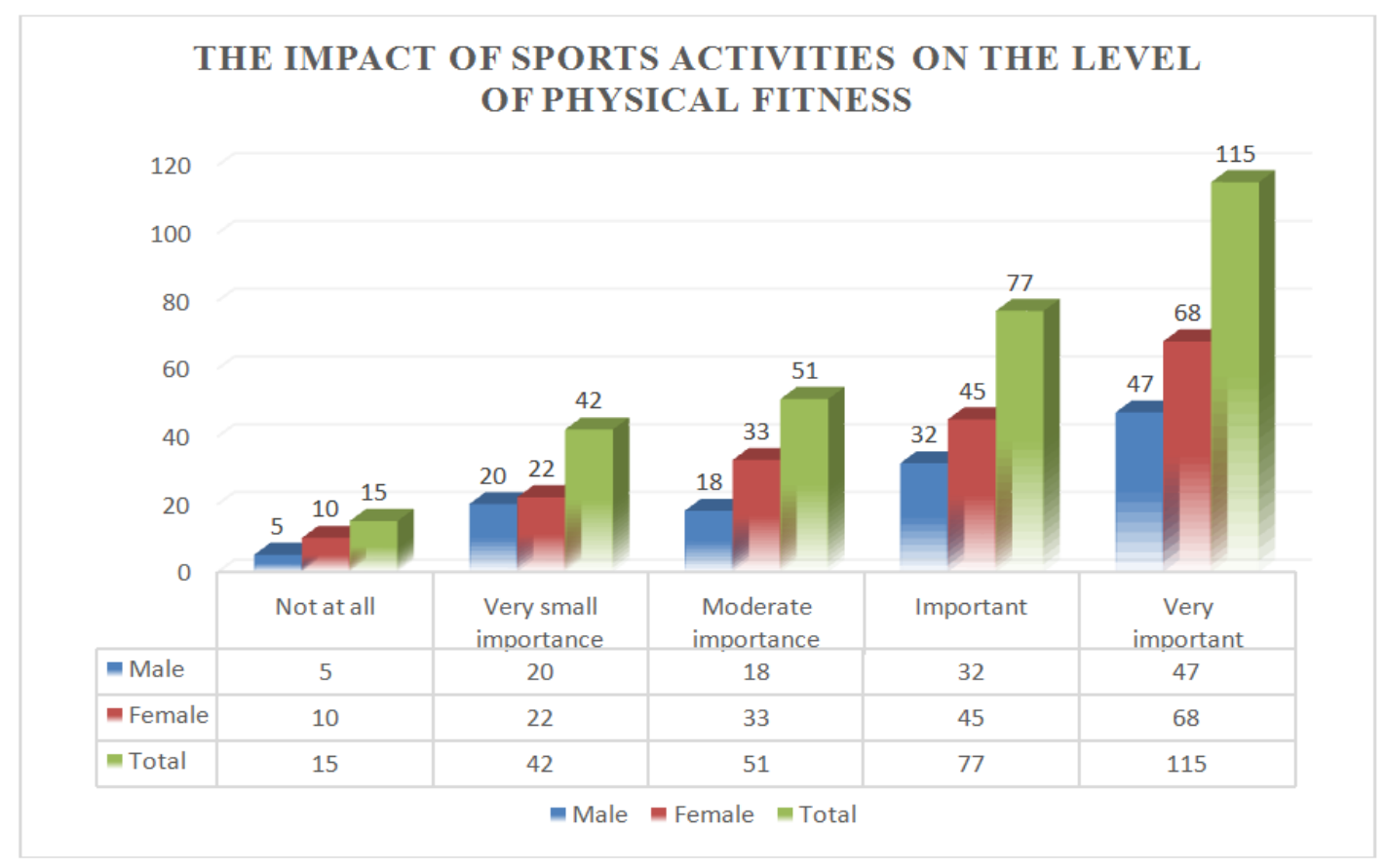

Figure no. 10: The impact of sports activities on the level of physical fitness

\section{Discussions}

Our questionnaire aimed to identify the lifestyle habits of students from "Lucian Blaga" University Sibiu, and how sports activities influence their health and motor development. So after we questioned the students sample we could outline the following:

At the first item regarding the influence of sports activities in improving or maintaining health parameters, the sample of students answered as follows: 8 students, representing $2.66 \%$ from the total, answered not at all showing that they don't think that sports activities can improve or maintain health parameters; 24 students, representing $8 \%$ from the total, answered with very small importance given to sports activities in health keeping; 41 students, representing $13.66 \%$ from the total, give moderate importance for sports activities in maintaining health, 143 students, representing $47.66 \%$ from the total, think that sports activities represent a way for maintaining health; and 25 students, representing $8.33 \%$ from the total, consider very important the sports activities in maintaining health.

Regarding the second item of the questionnaire that outlined sports activities as an important factor in developing communication, socialization and making friendships the students answered as follows: 27 students, representing $9 \%$, didn't consider at all sports as an important factor in making friendships and developing communication and socialization; 32 students, representing $10.66 \%$ from the total, affirmed that sports activities has very small importance in developing socialization skills; 34 students, representing $11.33 \%$ from the total, considered as moderate importance of sports activities in the development of socialization and communication; 77 students, representing $25.66 \%$ from the total, appreciate that sports activities are important in developing new friendships and socialization skills and 130 students, representing $43.33 \%$ from the total, considered that sports contribution to the development of new friendships, communication and socialization is very important. 
At the item importance of sports activities on moral values the students answered as follows: 8 students, representing $2.66 \%$, considered sports activities not important at all for developing and promoting moral values; 24 students, representing $8 \%$ from the total, thought that sports activities have a very small importance on moral values; 41 students, representing $13.67 \%$ from the total, give moderate importance to sports activities in building strong relationships; 101 students, representing $33.66 \%$ from the total, consider sports activities as an important factor in improving socialization and building new friendships; 126 students, representing $42 \%$ from the total amount of students, consider sports as a very important activity in building friendships and improving communication and socialization.

As we can see at item influence of sports activities on social values the results were: 9 students, representing $3 \%$ from the total, consider sport activities not important at all in promoting social values; 18 students, representing $6 \%$ from the total, affirm that sports activities have very small importance; 48 students, representing $16 \%$ from the total, appreciate that sports activities have a moderate importance on building social values for their practitioners; 75 students, representing $25 \%$ from the total, consider sports activities important in developing social values; 150 students, representing $50 \%$ from the total amount of students questioned, consider sports activities very important in developing social values.

At the item regarding sports activities and their involvement in improving the motivational level students answered as follows: 14 students, representing $4.66 \%$ from the total, consider that sports activities are not important at all for improving motivational level; 22 students, representing $7.33 \%$ from the total, thought that sports activities have a small importance on the motivational level; 46 students, representing
$15.33 \%$ from the total, give moderate importance of sports activities in improving the motivational level; 82 students, representing $27.33 \%$ from the total, consider important the sports activities in rising the motivational level and 136 students, representing $45.33 \%$ from the total, consider sports activities as an very important factor in developing the motivational level.

Regarding the item sports activities improve the need for constant practice of sport, the desire for self-improvement and the need for knowing your physical limits the students answered as follows: 6 students, representing $2 \%$ from the total, consider not important at all sports activities for self-improvement; 32 students, representing $10.66 \%$ from the total, thought that sports activities have a small importance on the desire for selfimprovement and the need for knowing physical limits; 53 students, representing $17.66 \%$ from the total, give moderate importance to sports activities in selfimprovement and braking physical limits; 80 students, representing $26.66 \%$ from the total, consider sport activities as important in the process of self-improving and 139 students, representing $46.33 \%$ from the total, consider sport activities very important in self-improvement and the need for knowing the physical limits.

Regarding the item influence of sports activities on mental and physical relaxation the students answered as follows: 12 students, representing $4 \%$ from the total, answer that sports activities are not important at all in the process of mental and physical relaxation; 35 students, representing $11.66 \%$ from the total, consider that sports activities very small importance for mental and physical relaxation; 65 students, representing $21.66 \%$ from the total, give moderate importance to sports activities for mental and physical relaxation; 67 students, representing $22.33 \%$ from the total, 
consider sports activities as important for mental and physical relaxation; 121 students, representing $40.33 \%$ from the total, thought that sports activities have a very important role in physical and mental relaxation.

At the last item regarding the impact of sports activities on the level of physical fitness, the students answered as follows: 15 students, representing $5 \%$ from the total, answered that sports activities are not important at all in keeping the physical fitness; 42 students, representing $14 \%$ from the total, consider that sports activities have little impact on the level of physical fitness; 51 students, representing $17 \%$ from the total, consider that sports activities have a moderate impact on physical fitness; 77 students, representing $25.66 \%$ from the total, thought that sports activities are important in building up a good physical fitness and 115 students, representing $38.33 \%$ from the total, consider that sports activities are very important in developing the level of physical fitness.

\section{Conclusions}

Our study focused on discovering the basic habits of students from our university regarding sports activity and students perception about the effects of sports activity on health and other social and moral values.

From the research results we can conclude that the majority of our students know the benefits of practicing sports activities and appreciate their effects.

Besides of the main motive for practice sports activities that was analysed in many other research - the benefit of maintain health, we discovered that also socialization and communication and making new friendship is what they are looking for. Also sports activities in students' opinion have an important role in building strong motivation, mental and physical relaxation.
Also other studies analysed sports effects from a psychological perspective, physically active individuals report higher levels of self-esteem and lower levels of anxiety, which also have both been associated with improved academic achievement (Flook et al., 2005).

One of the main motivations for sport, analyzed and discovered by specialists, is to create a healthy lifestyle through practicing physical exercises. According to experts, a healthy lifestyle is an active process that takes place during ontogenesis especially during maturity, the genetic inheritance being important and environment norms and values in which individuals live (Sopa et al. 2016).

Another study indicated that taking time away from traditional educational pursuits during the school day to spend an hour devoted to physical activity will not adversely influence performance of traditional educational skills (Carlson et al., 2008). Another study concluded that students who participate in physical activity programs in school are less likely to experience the adverse health complications resulting from degenerative diseases (Rennie et al., 2005). Many of the previous researches have already outlined the positive relationship between academic success and physical activity in the literature (e.g. Tomporowski et al., 2008; Chomitz et al., 2009; Tagoe and Dake, 2011; Turkmen, 2013).

In order to promote a healthier lifestyle for children, several attempts have been made, and many studies argued that education plays a vital role (James et al., 2004; Reynolds et al., 2000; Pate et al., 2005).

Taras (2005) also demonstrated that students who are physically active demonstrate greater attention during class than sedentary students. 


\section{REFERENCES}

Băiţel, I., \& Pătru, L. M. (2018). Influence of sport on laterality in children aged 9-11 years. International Congress of Physical Education, Sports and Kinetotherapy. Education and Sport Science in the $21^{\text {st }}$ Century, National University of Physical Education and Sport Bucharest, 72-81.

Benson, P. L., Scales, P. C., Hamilton, S. F., \& Sesma, A. (2006). Positive youth development: Theory, research and application. In W. Damon \& R. M. Lerner (Eds.), Handbook of child psychology, 894-941.

Canning, P., Courage, M., \& Frizzell, L. (2004). Prevalence of overweight and obesity in a provincial population of Canadian preschool children. J. Can. Med. Assoc. 171, 101-107.

Carlson, S. A., Fulton, J. E., Lee, S. M., Maynard, L. M., Brown, D. R., Kohl, H. W. \& Dietz, W. H. (2008). Physical education and academic achievement in elementary school: data from the early childhood longitudinal study. American Journal of Public Health, 98, 721-727.

Cârstea, G. (2000). Theory and methodics of physical education and sport. Bucharest: AN-DA Publishing House, 35-40.

Chomitz, V. R., Slining, M. M., McGowan, R. J., Mitchell, S. E., Dawson, G. F. \& Hacher, K. A. (2009). Is there a relationship between physical fitness and academic achievement? Positive results from public school children in the northeaster United States. Journal of School Health, 79, 30-37.

Dragnea, A., Stănescu, M., Teodorescu, S., Bota, A., Șerbănoiu, S., \& Tudor, V. (2006). Physical education and sport - theory and didactics. Bucharest: Fest Publishing House, 20-25.

Ebem, Z. (2007). Health Promoting Behaviours and Exercise Stages of Change Levels of Students at Transition to University. Ankara: Middle East Technical University Social Sciences Institute. Unpublished PhD Thesis, 40-49.

Elgar, F. J., Roberts, C., Moore, L., \& Tudor, S. C. (2005). Sedentary behavior, physical activity and weight problems in adolescents in Wales. Public Health. 119, 518-524.

Flook, L., Repetti, R. L. \& Ullman, J. B. (2005). Classroom social experiences as predictors of academic performance. Developmental Psychology, 41, 319-327.

Fromel, K., Kudlacek, M., Groffik, D., Svozil, Z., Simunek, A., \& Garbaciak, W. (2017). Promoting Healthy Lifestyle and Well-Being in Adolescents through Outdoor Physical Activity. International Journal of Environmental Research and Public Health, 14, 533.

Grigore, V. (2007). Exerciţiul fizic, factor determinant pentru prevenirea îmbătrânirii şi instalării bolilor degenerative. Bucureşti: Editura Didactică şi Pedagogică, 14.

Ionescu, C. L. (2012). Motric conduit, values and attitudes. Piteşti: Tiparg Publishing House, 125-130.

James, J., Thomas, P., Cavan, D., \& Kerr, D. (2004). Preventing childhood obesity by reducing consumption of carbonated drinks: Cluster randomised controlled trial. Br. Med. J. $328,1237-1241$.

Kelishadi, R., Alikhani, S., Delavari, A., Alaedini, F., Safaie, A., \& Hojatzadeh, E. (2008). Obesity and associated lifestyle behaviours in Iran: Findings from the First National Non-communicable Disease Risk Factor Surveillance Survey. Public Health Nutrition; 11, 246-251. 
Lyons, R., \& Langille, L. (2000). Healthy lifestyle: Strengthening the effectiveness of lifestyle approaches to improve health. Edmunton (AB): Health Canada, 112-123.

Macovei, S., Tufan, A. \& Vulpe, B. I. (2014). Theoretical Approaches to Building a Healthy Lifestyle through the Practice of Physical Activities. Elsevier Procedia - Social and Behavioral Sciences, 117, 86-91.

Neacşu, I. (2010). Pedagogie socială - valori, comportamente, experienţe, strategii. Bucureşti: Editura Universitară, 175.

Pate, R. R., Ward, D. S., Saunders, R. P., Felton, G., Dishman, R. K., \& Dowda, M. (2005). Promotion of Physical Activity among High-School Girls: A Randomized Controlled Trial. Am. J. Public Health, 95, 1582-1587.

Rășcanu, R. (2010). Psihologia sănătății: de la credințe și explicații la sisteme de promovare a ei. In Zlate, M., (coord) Psihologia la răspântia mileniilor. Iași: Editura Polirom, 199-228.

Rennie, K. L., Johnson, L., \& Jebb, S. A. (2005). Behavioral determinants of obesity. Best Practice \& Research. Clinical Endocrinology \& Metabolism, 19, 343-358.

Reynolds, K. D., Franklin, F. A., Binkley, D., Raczynski, J. M., Harrington, K. F., Kirk, K. A., \& Person, S. (2000). Increasing the fruit and vegetable consumption of fourth-graders: Results from the High 5 Project. Prev. Med. 30, 309-319.

Shipway, R. \& Holloway, I. (2010). Running free: Embracing a healthy lifestyle through distance running. Perspective in Public Health Pubmed, 270-276.

Sopa, I. S., \& Pomohaci, M. (2016). Study regarding the impact of motor activities over a healthy life of students. Buletin Știinţific vol. XXI, No. 2 (42), 115-122.

Sopa, I. S., \& Pomohaci, M. (2016). Study regarding the impact of physical education and sport on student's life from University "Lucian Blaga" Sibiu". Analele Universităţii din Oradea, Fascicula Educaţie Fizică şi Sport, Revista No. XXVI, 10-17.

Szabo, D. A. (2015). Modalities of using the information provided by the statistical program click and scout for improving the outside hitters' service efficiency in volleyball game. The European Proceeding of Social \& Behavioral Sciences EpSBS, 341-347.

Tagoe, H. A. \& Dake, F. A. (2011). Healthy lifestyle behaviour among Ghanaian adults in the phase of a health policy change. Globalization and Health, 7 (7), doi: 10.1186/17448603-7-7.

Taras, H. (2005). Physical activity and student performance at school. Journal of School Health, 6, 214-218.

Telama, R. (2009). Tracking of physical activity from childhood to adulthood: A review. Obes Facts, 2, 187-195.

Tomporowski, P. D., Davis, C. L., Miller, P. H. \& Naglieri, J. A. (2008). Exercise and children's intelligence, cognition, and academic achievement. Educational Psychology Review, 20, 111-131.

Turkmen, M., (2013). The relationships between gender, physical self-perception, sport experience, motivation orientations and academic success. International Journal of Academic Research Part B, 5 (5), B.10.

Yildirim, G. (2010). Physical Activity Behaviors and Neighborhood Walkability Perceptions of Turkish Women in Low and High Socio-Economic Environments. Ankara: Middle East Technical University Social Science Institute. Unpublished PhD Thesis, 236-244. 